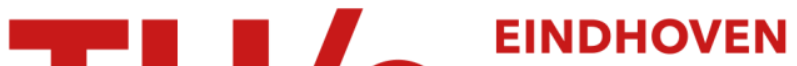 UNIVERSITY OF TECHNOLOGY
}

\section{The effect of $\mathrm{pH}$ profiles in methanogenic aggregates on the kinetics of acetate conversion}

\section{Citation for published version (APA):}

Beer, de, D., Huisman, J. W., Heuvel, van den, J. C., \& Ottengraf, S. P. P. (1993). The effect of pH profiles in methanogenic aggregates on the kinetics of acetate conversion. Water Research, 26(10), 1329-1336. https://doi.org/10.1016/0043-1354(92)90127-P

DOI:

10.1016/0043-1354(92)90127-P

Document status and date:

Published: 01/01/1993

\section{Document Version:}

Publisher's PDF, also known as Version of Record (includes final page, issue and volume numbers)

\section{Please check the document version of this publication:}

- A submitted manuscript is the version of the article upon submission and before peer-review. There can be important differences between the submitted version and the official published version of record. People interested in the research are advised to contact the author for the final version of the publication, or visit the $\mathrm{DOI}$ to the publisher's website.

- The final author version and the galley proof are versions of the publication after peer review.

- The final published version features the final layout of the paper including the volume, issue and page numbers.

Link to publication

\section{General rights}

Copyright and moral rights for the publications made accessible in the public portal are retained by the authors and/or other copyright owners and it is a condition of accessing publications that users recognise and abide by the legal requirements associated with these rights.

- Users may download and print one copy of any publication from the public portal for the purpose of private study or research.

- You may not further distribute the material or use it for any profit-making activity or commercial gain

- You may freely distribute the URL identifying the publication in the public portal.

If the publication is distributed under the terms of Article 25fa of the Dutch Copyright Act, indicated by the "Taverne" license above, please follow below link for the End User Agreement:

www.tue.nl/taverne

Take down policy

If you believe that this document breaches copyright please contact us at:

openaccess@tue.nl

providing details and we will investigate your claim. 


\title{
THE EFFECT OF pH PROFILES IN METHANOGENIC AGGREGATES ON THE KINETICS OF ACETATE CONVERSION
}

\author{
D. De Beer, J. W. Huisman, J. C. Van den Heuvel and S. P. P. Ottengraf \\ Laboratory for Chemical Engineering and Biotechnological Centre, Nieuwe Achtergracht 166, \\ 1018 WV Amsterdam, The Netherlands
}

(First received June 1991; accepted in revised form March 1992)

\begin{abstract}
Altract-Due to the conversion of acetic acid into the weaker carbonic acid and methane, the pH inside methanogenic aggregates is higher than in the bulk liquid. The pH profiles in aggregates were measured with pH microelectrodes. These profiles strongly determine the macro-kinetics of the aggregate, by their influence on the values of the growth parameters $K_{3}$ and $\mu_{\max }$. Acetate transport resistances were not limiting for the conversion rate in methanogenic aggregates. Nevertheless, the effectiveness factor $\eta$ did not approach unity, but amounted to $0.57-0.62$ in the acetate concentration range relevant for most methanogenic reactors. The value of $\eta$ is determined almost entirely by the $\mathrm{pH}$ profiles inside the aggregates. It was concluded that for the physical/mathematical description of the conversion in methanogenic aggregates, information on the $\mathrm{pH}$ gradients and the $\mathrm{pH}$ dependency of the growth parameters is indispensable.

Batch experiments showed that acetate uptake by aggregates was not coupled directly to methanogenesis. Consumed acetate was not converted instantaneously to methane, suggesting the conversion to proceed via a pool of acetate or reserve material.
\end{abstract}

Key words - methanogenesis, acetate digestion, aggregates, microenvironment, mass transfer, microelectrodes, macro-kinetics, growth, pH

\section{NOMENCLATURE}

$D=$ subatrate diffusion coefficient $\left(\mathrm{m}^{2} / \mathrm{s}\right)$

$D_{\text {aff }}=$ efiective difiusion coefficient $\left(\mathrm{m}^{2} / \mathrm{s}\right)$

$\hat{k}=$ mass transfer coefficient $(\mathrm{m} / \mathrm{s})$

$K_{\mathbf{z}}=$ disaciation constant $\left(\mathrm{mol} / \mathrm{m}^{3}\right)$

$\boldsymbol{K}=$ Monod saturation constant $\left(\mathrm{mol} / \mathrm{m}^{3}\right)$

$\boldsymbol{K}_{\mathrm{s}}^{\prime}=$ Monod saturation constant for unionized acetic acid $\left(\mathrm{mol} / \mathrm{m}^{3}\right)$

$K_{i}^{\prime \prime}=$ pH dependent Monod saturation constant, related to total substrate $\left(\mathrm{mol} / \mathrm{m}^{3}\right)$

$r=$ distance from centre $(\mathrm{m})$

$r_{s}=$ reaction rate $\left(\mathrm{mol} / \mathrm{m}^{3} \mathrm{~s}\right)$

$\boldsymbol{R}=$ agrograte radius $(\mathrm{m})$

$S=$ total substrate concentration $\left(\mathrm{mol} / \mathrm{m}^{3}\right)$

$S_{b}=$ total substrate concentration in the bulk $\left(\mathrm{mol} / \mathrm{m}^{3}\right)$

$S_{\mathrm{i}}=$ total substrate concentration at aggregate interface $\left(\mathrm{mol} / \mathrm{m}^{3}\right)$

HAc $=$ unionized acetic acid concentration $\left(\mathrm{mol} / \mathrm{m}^{3}\right)$

$A c^{-}=$ionized substrate concentration $\left(\mathrm{mol} / \mathrm{m}^{3}\right)$

$V_{m}=$ convervion rate per aggregate $(\mathrm{mol} / \mathrm{s})$

$V_{\max }=$ maximal conversion rate of an aggregate without $\mathrm{pH}$ micro-profile $(\mathrm{mol} / \mathrm{s})$

$Y_{\text {bio }}=$ biomass yield (g dry $\mathrm{wt} / \mathrm{mol}$ )

$\breve{Y}_{p}=$ product yield $(\mathrm{mol} / \mathrm{mol})$

$X=$ biomass concentration $\left(g / \mathrm{m}^{3}\right)$

$\delta=$ diffusional boundary layer thickness $(\mathrm{m})$

$\eta=$ effectivenes factor $(-)$

$\mu_{\max }^{\prime}=$ maximal specific growth rate at pH $7.0(1 / \mathrm{s})$

$\mu_{\max }=$ maximal specific growth rate at prevailing pH (1/s)

\section{INTRODUCTION}

For the treatment of wastewater with a high organic matter content anaerobic processes are increasingly applied. Anaerobic wastewater treatment is a multistep process in which soluble organics are degraded to fatty acids and, subsequently, converted to methane and carbonate. Methanogenesis involves a complex interaction of conversions by various microbial species (Zeikus, 1980; Dubourguier et al., 1987). The digestion of acetate is responsible for $65-96 \%$ of the methane formation (Weber et al., 1984). Moreover, conversion of acetate to methane is considered as the rate limiting step in the methane production from wastewater (McCarthy, 1964). Therefore, knowledge of the kinetics of this process is necessary for the design and operation of methane reactors.

The Monod equation is widely used for the modelling of the anaerobic digestion process. The kinetic parameters that describe the performance of a bioreactor to a large extent are the maximum specific growth rate $\left(\mu_{\max }\right)$, the substrate saturation constant $\left(K_{\mathrm{s}}\right)$ and the product yield $\left(Y_{\mathrm{p}}\right)$. Usually, these constants are determined from a series of continuous flow or batch experiments with enrichment or pure cultures (Zehnder et al., 1980; Huser et al., 1982; Yang and Okos; 1987). This method is very elaborate, especially with methanogens. A more serious disadvantage is the fact that in high performance bioreactors methanogens do not grow in suspension, but form aggregates with a typical diameter of 1-3 mm. Therefore, suspended growth experiments can be considered as studies on artifacts. Conversely, the aim of this study is to determine the kinetic 
parameters of the methanogenic acetate conversion on intact aggregates.

In active bacterial aggregates, profiles of substrate and product will develop. In methanogenic aggregates $\mathrm{pH}$ profiles are also formed by the conversion of acetic acid into the weaker carbonic acid. These profiles are dependent on the size of the aggregate and the complex interaction of diffusion, kinetics of the conversion processes and the distribution of the bacterial activity. Since the kinetics and the $\mathrm{pH}$ profile are interdependent, calculations on this system are very complex. In this study the $\mathrm{pH}$ profiles present in methanogenic aggregates were actually measured and this information was used to calculate substrate profiles and conversion rates.

Comparison of measured conversion rates with calculations using a structured mathematical model enabled the estimation of the relevant growth parameters, and the significance of $\mathrm{pH}$ profiles in aggregates for reactor operation was evaluated.

\section{MATERIALS AND METHODS}

\section{Measurements}

Methanogenic aggregates were sampled from a pilotscale Internal Circulation reactor (Paques BV, Balk. The Netherlands) treating brewery wastewater (Heineken BV, 's-Hertogenbosch, The Netherlands). Since this reactor is $17 \mathrm{~m}$ high, precautions had to be taken to prevent the aggregates from damage by fast pressure drops during sampling. Therefore, sampling was done in a vessel pressurized with $\mathrm{CO}_{2}$ at $2.5 \mathrm{~atm}$. After the vessel was filled with reactor content, the pressure was released slowly.

Activity tests on intact aggregates and micro-profile measurements were performed in a mineral medium containing $\mathrm{NH}_{4} \mathrm{Cl}\left(5 \mathrm{~mol} / \mathrm{m}^{3}\right), \mathrm{KCl}\left(0.6 \mathrm{~mol}, / \mathrm{m}^{3}\right), \mathrm{NaH}_{2} \mathrm{PO}_{4}$ $\left(0.5 \mathrm{~mol} / \mathrm{m}^{3}\right), \mathrm{Na}_{2} \mathrm{SO}_{4}\left(0.08 \mathrm{~mol} / \mathrm{m}^{3}\right), \mathrm{MgCl}_{2}\left(0.062 \mathrm{~mol} / \mathrm{m}^{3}\right)$, $\mathrm{CaCl}_{2}\left(0.001 \mathrm{~mol} / \mathrm{m}^{3}\right)$, citric acid $\left(0.1 \mathrm{~mol} / \mathrm{m}^{3}\right) . \quad \mathrm{Na}_{2} \mathrm{MoO}_{4}$ $\left(6 \times 10^{-6} \mathrm{~mol} / \mathrm{m}^{3}\right), \quad \mathrm{NaSeO}_{4}\left(3 \times 10^{-5} \mathrm{~mol} / \mathrm{m}^{3}\right), \quad \mathrm{NiSO}_{4}$ $\left(1.5 \times 10^{-4} \mathrm{~mol} / \mathrm{m}^{3}\right), \quad \mathrm{FeCl}_{3} \quad\left(0.005 \mathrm{~mol} / \mathrm{m}^{3}\right), \quad \mathrm{MgCl}_{2}$ $\left(0.003 \mathrm{~mol} / \mathrm{m}^{3}\right), \mathrm{CoCl}_{2}\left(0.0005 \mathrm{~mol} / \mathrm{m}^{3}\right), \mathrm{ZnO}(0.00125 \mathrm{~mol} /$ $\left.\mathrm{m}^{3}\right), \mathrm{CuCl}_{2}\left(0.00025 \mathrm{~mol} / \mathrm{m}^{3}\right)$ and $\mathrm{H}_{3} \mathrm{BO}_{3}\left(0.00025 \mathrm{~mol} / \mathrm{m}^{3}\right)$. These nutrients were supplied with the desired concentration of acetate, flushed with $\mathrm{N}_{2}$ and adjusted to $\mathrm{pH} 7.0$. The conversion rate of aggregates was measured in $500 \mathrm{ml}$ serum bottles containing $750-1500 \mathrm{mg}$ dry wt. The incubation temperature was $30^{\circ} \mathrm{C}$ and the acetate concentration was maintained at $90-100 \%$ of the desired value by addition of $1900 \mathrm{~mol} / \mathrm{m}^{3}$ acetate of $\mathrm{pH} 5.0$. During these fed-batch cultures, the $\mathrm{pH}$ of the medium varied from 6.9 to 7.1 . Acetate consumption was determined by gas chromatography. Methane production was measured with mariotte bottles containing $1500 \mathrm{~mol} / \mathrm{m}^{3} \mathrm{NaOH}$.

The effectiveness factor $(\eta)$ was determined from the increase of the conversion rate upon disintegration of aggregates and calculated as the quotient of the activity before and after disintegration. Disintegration of the aggregates in separate cells or fragments smaller than $50 \mu \mathrm{m}$ was achieved in $2 \mathrm{~h}$ with a magnetic stirrer at $250 \mathrm{rpm}$.

Measurements of $\mathrm{pH}$ profiles were performed in a flowcell using pH-microelectrodes with a tip diameter of $1 \mu \mathrm{m}$, as described previously (de Beer and Van den Heuvel, 1988). The dimensions of the aggregate were determined with a vernier calliper. Since aggregates are not perfectly spherical, a characteristic diameter was calculated from the mean diameters in the $x, y$ and $z$ direction. The Sauter mean diameter of the sample was determined with an image analysing system (Shieh et al., 1981).

\section{Calculations}

Substrate profiles in spherical microbial aggregates can be obtained from a substrate mass balance comprising diffusion and reaction:

$$
\left(D_{\mathrm{eft}} / r^{2}\right) \mathrm{d}\left(r^{2} \mathrm{~d} S / \mathrm{d} r\right) / \mathrm{d} r=-r_{\mathrm{s}} .
$$

The reaction rate depends on the specific growth rate $\mu$, the local biomass concentration $X$ and the biomass yield. Neglecting maintenance, substrate consumption can be described with Monod kinetics:

$$
-r_{\mathrm{s}}=\mu X / Y_{\text {bio }}=\left(\mu_{\max } X / Y_{\text {bio }}\right) S /\left(K_{s}+S\right) \text {. }
$$

As the acetate concentration range applied is well below the substrate inhibiting concentration (Speece, 1988) no inhibition kinetics were considered. Graef and Andrews (1973) postulated that unionized acetic acid is the actual substrate for methanogens. Accordingly, the reaction rate is described by

$$
\left.\mu X / Y_{\text {bio }}=\left(\mu_{\max } X / Y_{\text {bio }}\right) \text { HAc/(Ks }+ \text { HAc }\right) .
$$

The concentration of the unionized acetic acid depends on the $\mathrm{pH}$ and, for the relevant $\mathrm{pH}$ range of 7.0-8.0, $\mathrm{Ac}^{-} \approx S$ and since the acid-base reaction is in equilibrium momentarily

$$
\mathrm{HAc}=\left(\mathrm{H}^{+} \cdot S\right) / K_{\mathrm{a}} .
$$

Equation (3) can be rewritten as

$$
\mu X / Y_{\text {bio }}=\left(\mu_{\max } X / Y_{\text {bio }}\right) S /\left(K_{s}^{\prime \prime}+S\right)
$$

with

$$
K_{\mathrm{s}}^{\prime \prime}=K_{\mathrm{s}}^{\prime} \cdot K_{\mathrm{a}} / \mathrm{H}^{+} .
$$

The saturation constant $K_{\mathrm{s}}^{n}$ refers to the total concentration of both forms of acetate and depends on the pH. Equation (1) can now be rewritten as

$$
\left(D_{\mathrm{eff}} / r^{2}\right) \mathrm{d}\left(r^{2} \mathrm{~d} S / \mathrm{d} r\right) / \mathrm{d} r=\left(\mu_{\max } X / Y_{\mathrm{bio}}\right) S /\left(K_{\mathrm{s}}^{\prime \prime}+S\right) .
$$

This equation cannot be solved analytically, therefore, a Runge-Kutta iteration was used with boundary conditions (i) $\mathrm{d} S / \mathrm{d} r=0$ at $r=0$, and (ii) $D_{\mathrm{eff}}(\mathrm{d} S / \mathrm{d} r)_{(r+R)}=$ $k\left(S_{\mathrm{b}}-S_{\mathrm{i}}\right)=D\left(S_{\mathrm{b}}-S_{\mathrm{i}}\right) / \delta$. The experimental relation between $\mu_{\max }$ and the $\mathrm{pH}$ from Van den Berg et al. (1975) was approximately by a Gaussian curve:

$$
\mu_{\max }=\mu_{\max }^{\prime} \cdot \mathrm{e}^{-0.51(\mathrm{pH}-7) / 0.62) 2}
$$

where $\mu_{\max }^{\prime}$ represents the value of $\mu_{\max }$ at $\mathrm{pH}=7.0$. The effective diffusion coefficient of acetate inside the aggregates was conservatively assumed to be $4.2 \times 10^{-10} \mathrm{~m}^{2} / \mathrm{s}$, which is $34 \%$ (Speece, 1988) of the value in pure water (Perry and Green, 1984), $Y_{\text {bio }}$ was set at $1.5 \mathrm{~g}$ biomass dry $w t / \mathrm{mol}$ acetate (de Zeeuw, 1984).

Equation (7) was used to calculate the conversion rate of a single aggregate $V_{\text {acs }}$ at different bulk substrate concentrations. Comparison of calculated conversion rates at various substrate concentrations with measured data enabled determination of $\mu_{\max }^{\prime}$ and $K_{\mathrm{s}}$ at $\mathrm{pH} 7$.

Effectiveness factors $(\eta)$ at various acetate concentrations in the bulk liquid $\left(S_{b}\right)$ were calculated using

$$
\eta=V_{\text {ugd }} /\left(V_{\max } S_{\mathrm{b}} /\left(K_{\mathrm{s}}+S_{\mathrm{b}}\right)\right)
$$

where $V_{\max }$ is the theoretical maximal conversion rate per aggregate without diffusion resistance, i.e. with a constant acetate concentration and $\mathrm{pH}$ throughout the aggregate, and is given by

$$
V_{\max }=\left(\mu_{\max }^{\prime} X / Y_{\text {bio }}\right) 4 / 3 \pi R^{3}
$$

\section{Electron microscopy}

Aggregates were washed gently in $150 \mathrm{~mol} / \mathrm{m}^{3} \mathrm{NaCl}$, followed by fixation in $2.5 \%$ glutaraldehyde for $1 \mathrm{~h}$. 


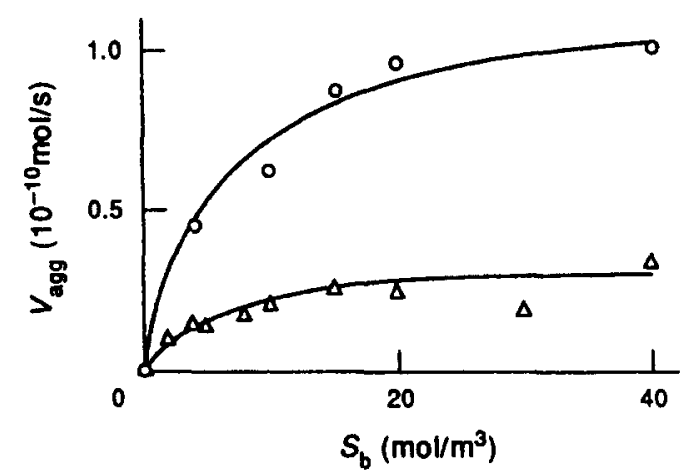

Fig. 1. Acetate consumption $(O)$ and methane production $(\triangle)$ rates of methanogenic aggregates, incubated at different acetate concentrations in the bulk liquid.

Aggregates were dehydrated in an ethanol series from 15 , $30,45,60,70,85$ and $100 \%$, made up with $150 \mathrm{~mol} / \mathrm{m}^{3}$ $\mathrm{NaCl}$. Subsequently, the aggregates were submitted to critical-point drying in liquid carbon dioxide. Dry aggregates were mounted on SEM stubs with silver paint, sputter

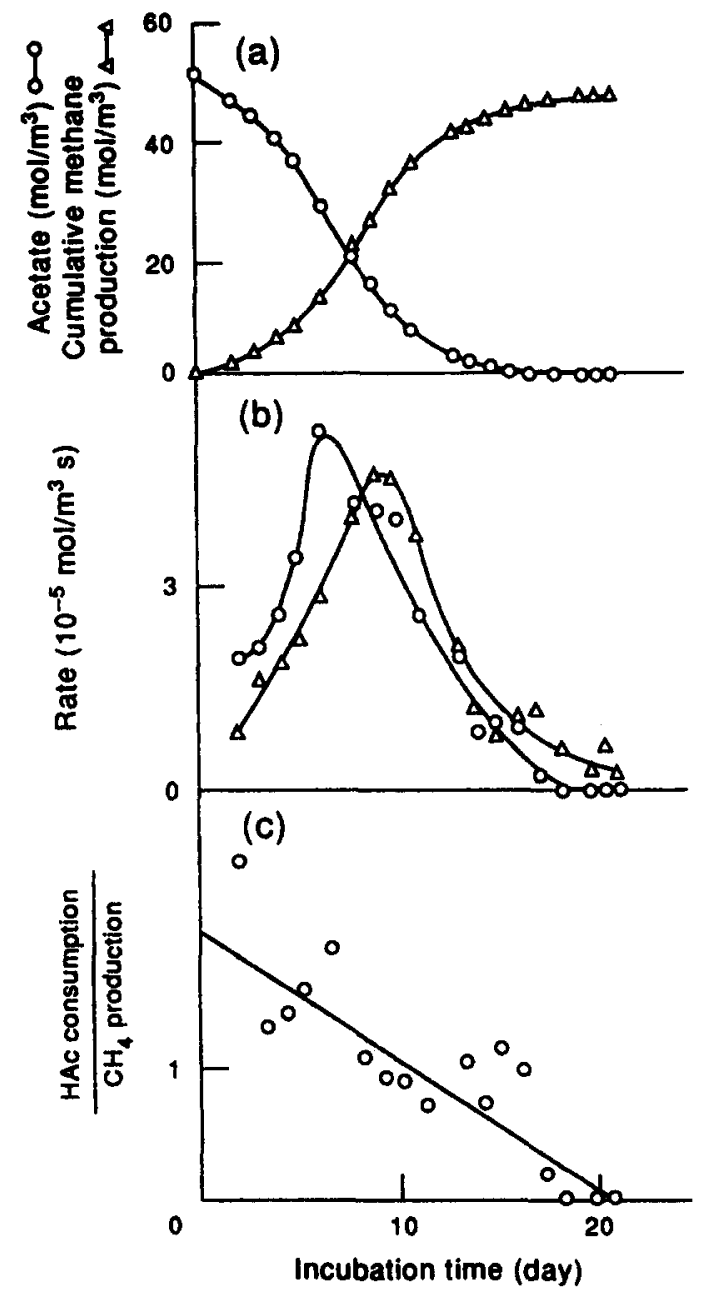

Fig. 2. Relation between the acetate consumption and the methane production by methanogenic aggregates during a long term incubation. (a) Acetate concentration (O) and cumulative methane production $(\Delta)$, (b) acetate consumption $(O)$ and methane production rate $(\Delta)$ and (c) ratio of acetate consumption rate and methane production rate during the experiment.

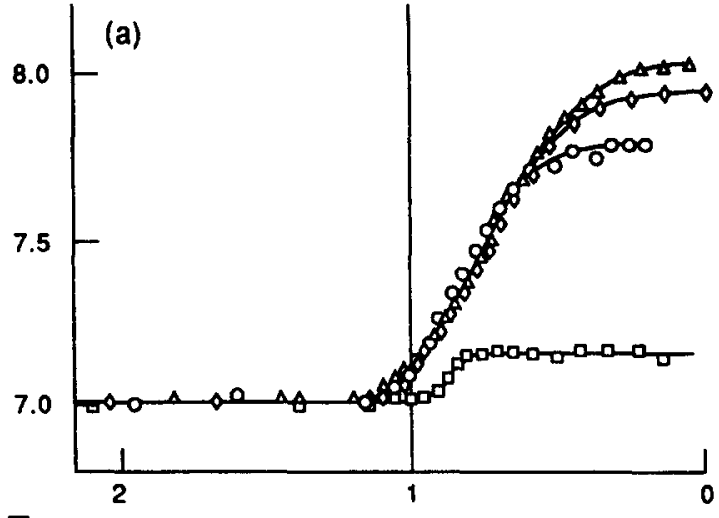

$\frac{T}{0}$

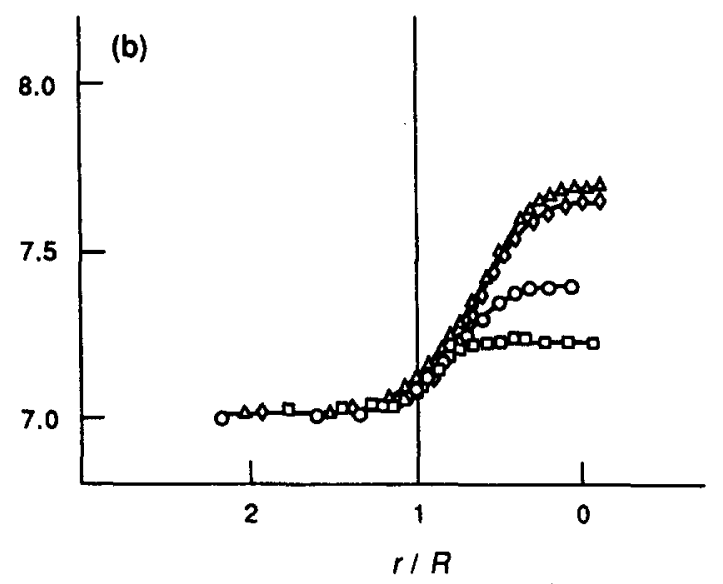

Fig. 3. pH microprofiles measured in methanogenic aggregates with a characteristic diameter of $2.2 \times 10^{-3} \mathrm{~m} \mathrm{(a)}$ and $1.3 \times 10^{-3} \mathrm{~m}(\mathrm{~b})$, incubated in acetate concentrations of $0 \mathrm{~mol} / \mathrm{m}^{3}(\square), 5 \mathrm{~mol} / \mathrm{m}^{3}(O), 10 \mathrm{~mol} / \mathrm{m}^{3}(\diamond)$ and $15 \mathrm{~mol} / \mathrm{m}^{3}$ $(\triangle)$.

coated with gold/palladium, and examined in a scanning electron microscope (ISI-DS 130).

\section{RESULTS}

Electron microscopy revealed that the aggregates consisted almost exclusively of rod-shaped bacteria, most likely belonging to the genus Methanothrix, which are commonly found in sewage digesters (Zehnder et al., 1980).

Acetate consumption and methane production rates of aggregates at different acetate bulk concentrations in fed-batch are presented in Fig. 1, showing maximal conversion rates were reached at acetate concentrations of $15-20 \mathrm{~mol} / \mathrm{m}^{3}$. From these results, it is clear that the consumption rate of acetate in the activity test was about three times higher than the production rate of methane.

To investigate the stoichiometry of the microbial conversion, acetate consumption and methane production by aggregates were monitored during a long term batch experiment, which was terminated after acetate was depleted and methanogenesis had stopped. The results of this experiment are pictured in Fig. 2. During the first 8 days of the experiment 


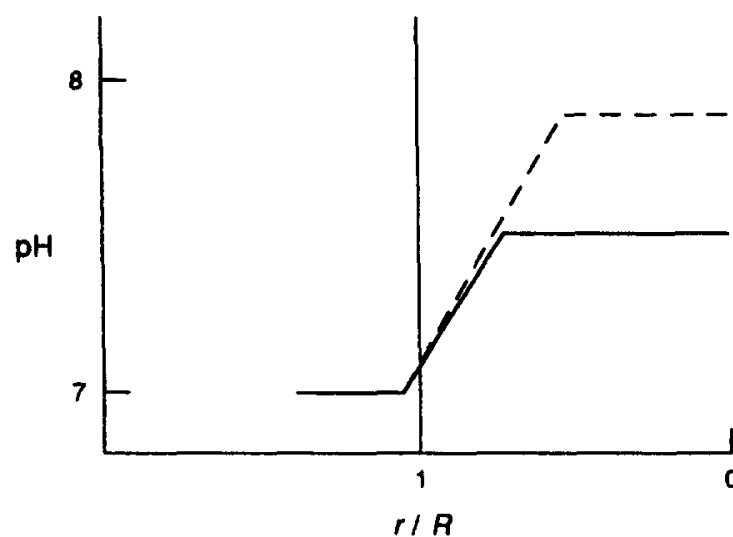

Fig. 4. Simplified pH profiles used in the structured model for calculations on transport and conversion in methanogenic aggregates, at acetate concentrations of 5 (solid line) and $10 \mathrm{~mol} / \mathrm{m}^{3}$ or more (dotted line).

acetate consumption was higher than methane production, conversely, after day 8 methane production exceeded the acetate consumption [Fig. 2(b)]. After the acetate was depleted completely at day 17 , the methane production continued for a period of 4 days. As a consequence, the ratio of the acetate consumption rate and the methane production rate, during the experiment, initially exceeded 1 , subsequently decreased and was eventually reduced to 0 [Fig. 2(c)]. Upon termination, the total amount of consumed acetate was $51 \mathrm{mmol}$, from which $48 \mathrm{mmol}$ of methane was produced, resulting in an overall stoichiometry of 1.06. Clearly, during the experiment acetate consumption and methane production were not synchronous. Part of the acetate consumed was not converted instantaneously to methane, although eventually its conversion to methane was stoichiometric.

In an additional experiment in medium that, in contrast to the usual medium, was buffered with $10 \mathrm{~mol} / \mathrm{m}^{3}$ phosphate at a $\mathrm{pH}$ value of 7 , no signifi-

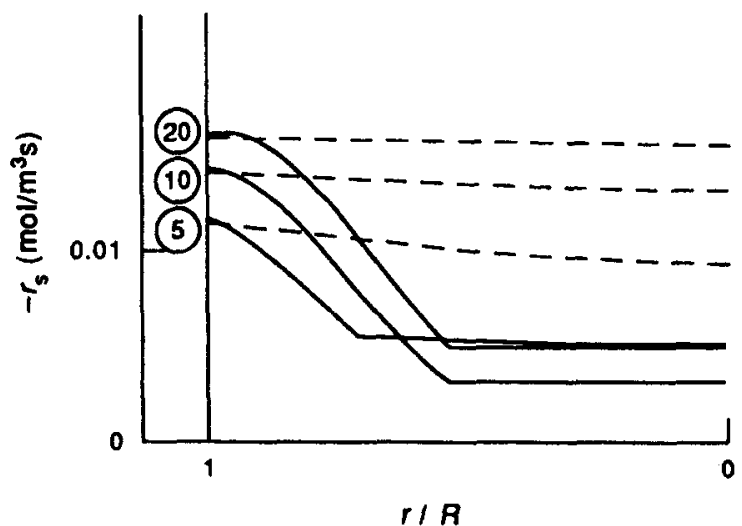

Fig. 5. Activity profiles, calculated from growth parameters based on methane formation, in methanogenic aggregates, with a diameter of $1.64 \times 10^{-3} \mathrm{~m}$, at difierent acetate concentrations with (solid line) and without (dotted line) $\mathrm{pH}$ gradients. Encircled numbers indicate the acetate concentration in the bulk liquid.

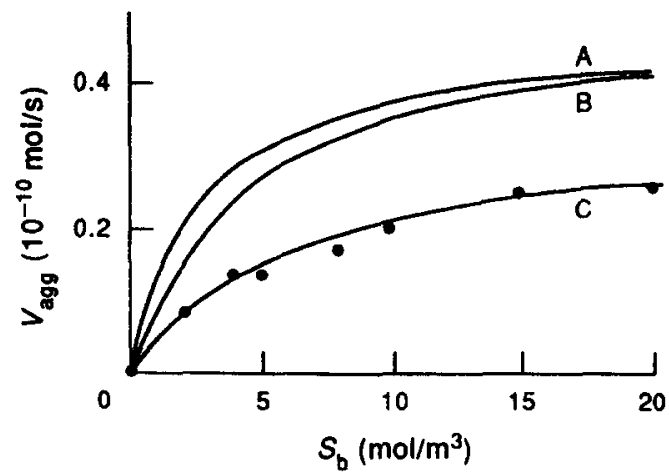

Fig. 6. Conversion rate of a single aggregate at various acetate concentrations in the bulk liquid. Calculated (A) for an aggregate with no diffusion resistance for acetate and without $\mathrm{pH}$ gradients, (B) for an aggregate with diffusion resistance for acetate and without $\mathrm{pH}$ gradients and (C) for an aggregate with both diffusion resistance for acetate and $\mathrm{pH}$ profiles from Fig. 4. Solid circles indicate measured values.

cant influence of the substrate concentration on the conversion rate was observed. In the acetate concentration range of $5-30 \mathrm{~mol} / \mathrm{m}^{3}$, the maximal conversion rate was already reached at a concentration of $5 \mathrm{~mol} / \mathrm{m}^{3}$ (data not shown).

Incorporation of the developing $\mathrm{pH}$ micro-profiles in the structured model is essential, since the growth parameters $\mu_{\max }$ and $K_{\mathrm{s}}$ are strongly dependent on the local $\mathrm{pH}$ value. Therefore, $\mathrm{pH}$ profiles in aggregates were measured at various acetate concentrations in the bulk liquid under steady state conditions. These measurements were performed on 50 aggregates. The average characteristics diameter of all the aggregates in which profiles were measured was $1.64 \mathrm{~mm}$, while the Sauter mean of the total sample was $1.58 \mathrm{~mm}$. In Fig. 3 a few characteristic $\mathrm{pH}$ profiles are presented. The $\mathrm{pH}$ inside aggregates was higher than the bulk $\mathrm{pH}$, as could be expected since the stronger acetic acid was replaced by the weaker carbonic acid. Also in the absence of acetate in the bulk liquid, $\mathrm{pH}$ gradients were observed although very small. In a concentration range from 0 to $10 \mathrm{~mol} / \mathrm{m}^{3}$, relevant for most anaerobic reactors, the maximal $\mathrm{pH}$ value inside the aggregates increased with higher acetate concentrations in the bulk. Further increase of the acetate concentration only caused a slight increase of the internal $\mathrm{pH}$. At an acetate concentration of $5 \mathrm{~mol} / \mathrm{m}^{3}$ the $\mathrm{pH}$ increased to a depth of $280( \pm 40) \mu \mathrm{m}$, while a plateau was apparent in the centre. At acetate concentrations of $10 \mathrm{~mol} / \mathrm{m}^{3}$ or higher, a $\mathrm{pH}$ increase was observed down to a larger depth of $410( \pm 60) \mu \mathrm{m}$. In aggregates incubated in medium, buffered with $10 \mathrm{~mol} / \mathrm{m}^{3}$ phosphate, no $\mathrm{pH}$ gradients developed (data not shown).

The measured $\mathrm{pH}$ profiles were used to calculate acetate concentration profiles and conversion rates in aggregates. For this purpose simplified mean $\mathbf{p H}$ profiles were composed as given in Fig. 4. The measurement of $\mathrm{pH}$ profiles revealed that they also extended outside the actual aggregate, indicating a 
Table 1. Effectiveness factors $\eta$ of aggregates at various acetate bulk concentrations $(A)$ calculated using the structured model when no $\mathrm{pH}$ profiles occur, (B) calculated using the structured mode including $\mathrm{pH}$ profiles and (C) values obtained from the increase of activity upon disintegration into cells

\begin{tabular}{lccc}
\hline & \multicolumn{3}{c}{ Efiectiveness factor $\eta$} \\
\cline { 2 - 4 }$S_{\mathrm{b}}\left(\mathrm{mol} / \mathrm{m}^{3}\right)$ & A & B & C \\
\hline 5 & 0.92 & 0.57 & 0.62 \\
10 & 0.96 & 0.62 & 0.42 \\
15 & 0.98 & 0.63 & 0.61 \\
20 & 0.99 & 0.63 & 0.53 \\
\hline
\end{tabular}

diffusive boundary layer outside the biofilm (Fig. 3). Therefore, in the calculations on substrate transport and conversion the presence of such a boundary layer of $50 \mu \mathrm{m}$ thickness was assumed. Calculations were performed using the average aggregate diameter of $1.64 \mathrm{~mm}$.

By comparing calculated conversions at various acetate concentrations in the bulk liquid with the fed-batch measurements on aggregates presented in Fig. 1, a fit based on acetate consumption was found using $\mu_{\max }^{\prime}=6.9 \times 10^{-7} \mathrm{~s}^{-1}$ and $K_{\mathrm{s}}=2.1 \mathrm{~mol} / \mathrm{m}^{3}$, while based on methane production a fit was found with $\mu_{\max }^{\prime}=2.1 \times 10^{-7} \mathrm{~s}^{-1}$ and $K_{\mathrm{s}}=2.6 \mathrm{~mol} / \mathrm{m}^{3}$.

Calculations of the local activities in the aggregates are pictured in Fig. 5, showing that even for homogeneously distributed active biomass, the conversion rate strongly depended on the location, although acetate penetrated the whole aggregate and its concentration was close to that of the bulk liquid under the applied conditions. It was calculated that the acetate concentrations in the centre of aggregates incubated in 5,10 or $20 \mathrm{~mol} / \mathrm{m}^{3}$ acetate amounted to $3.73,8.59$ and $18.33 \mathrm{~mol} / \mathrm{m}^{3}$. The difference between the local conversion rates calculated with and without pH profiles, shows that the local conversion rate is much more influenced by the $\mathrm{pH}$ value than by the acetate concentration. The low activity in the centre of the aggregates is caused mainly by the high local $\mathrm{pH}$ value. Figure 5 shows that the activity in the centre of the aggregates may even decrease at higher substrate concentrations due to the more pronounced $\mathrm{pH}$ profile, although the activity of the total aggregate is positively related to the substrate concentration (Fig. 6).

In Fig. 6 measured and calculated conversion rates of a single aggregate at various acetate concentrations in the bulk liquid are presented. These calculations were done to establish the influence of the mass transfer resistance for acetate and the role of $\mathrm{pH}$ profiles on the conversion rate and the effectiveness factor. The differences of the curves underline the importance of the $\mathrm{pH}$ profiles. From comparison of curves (A) and (B) it is clear that the influence of acetate transport limitation by external and internal diffusion resistances is insignificant for the conversion rate in aggregates. Comparison of curves (B) and (C) shows that the local $\mathrm{pH}$ values determine the conversion rate to a much higher extent.

In Table 1 values for effectiveness factor $\eta$ are presented that were calculated with the structured model with and without $\mathrm{pH}$ profiles, together with values determined from the increase of the conversion rate upon disintegration of aggregates. In all cases, $\eta$ is almost independent of the substrate concentration in the bulk. Experimental values are in agreement only with those calculated using the structured model if $\mathrm{pH}$ micro-profiles were taken into account.

\section{DISCUSSION}

The value for $\mu_{\max }^{\prime}$ of Methanothrix soehngenii found in previous studies with suspended pure and enrichment cultures are slightly higher but of the same order of magnitude as our estimations for methanogenic aggregates based on acetate consumption rates (see Table 2). However, the value for $\mu_{\max }^{\prime}$ obtained from methane production is significantly lower. Estimations of $K_{\mathrm{s}}$ based on acetate consumption and methane production resulted in values 2-5 times higher as found by other authors.

The estimations presented in this study are based on the assumption that methanogenesis and growth are strictly coupled by a constant yield factor under all experimental conditions. Although the conclusive verification of this assumption is difficult, it is supported by the observation that methanogenesis by Methanobacterium, growing on $\mathrm{H}_{2}$ and $\mathrm{CO}_{2}$, is strictly coupled to biomass growth in the $\mathrm{pH}$ range from 7.5 to 8.9 (Zehnder and Wuhrmann, 1977). Most yield factors on acetate found previously under different conditions are in the range from 1.3 to $1.95 \mathrm{~g} / \mathrm{mol}$ (Graef and Andrews, 1973; Weber et al., 1984; Yang and Okos, 1987; de Zeeuw, 1984), however, a value of 2.82 has been reported as well (Zehnder et al., 1980). If the latter value is used, the estimation of $\mu_{\max }^{\prime}$ based on acetate consumption becomes $1.3 \times 10^{-7} \mathrm{~s}^{-1}$, which is in between the two values reported previously for Methanothrix soehngenii

Table 2. Comparison of results from this study with those obtained in studies on suspended bacteria

\begin{tabular}{|c|c|c|}
\hline$\mu_{\max }^{\prime}(1 / \mathbf{s})$ & $K_{\mathrm{s}}\left(\mathrm{mol} / \mathrm{m}^{3}\right)$ & Source \\
\hline $8.9 \times 10^{-9}$ & 0.47 & Methanothrix soehngenii (Zehnder et al.. 1980) \\
\hline $\begin{array}{l}1.6 \times 10^{-6} \\
1.1 \times 10^{-6}\end{array}$ & $\begin{array}{l}0.70 \\
1.17\end{array}$ & $\begin{array}{l}\text { Methanothrix soehngenii (Huser et al., 1982) } \\
\text { Disintegrated aggregates, pH 7.3, based on acetate } \\
\text { consumption (Hamelers and Koster, 1986) }\end{array}$ \\
\hline $6.9 \times 10^{-7}$ & 2.1 & $\begin{array}{l}\text { Intact aggregates, based on fitting of acetate consumption } \\
\text { with model calculations (this study) }\end{array}$ \\
\hline $2.1 \times 10^{-7}$ & 2.6 & $\begin{array}{l}\text { Intact aggregates, based on fitting of methane production } \\
\text { with model calculations (this study) }\end{array}$ \\
\hline
\end{tabular}


(Zehnder et al., 1980; Huser et al., 1982), and close to the value obtained for disintegrated aggregates (Hamelers and Koster, 1986). No conclusive answer can be found for the question why the estimation of $K_{\mathrm{s}}$ is relatively high as compared to other authors. In this study $K_{\mathrm{s}}$ was determined by fitting the macrokinetics of intact aggregates with a mathematical model, while the other authors made use of suspended bacteria. The latter method might be more precise. Alternatively, growth parameters of bacteria in aggregates could be different from those of freely suspended bacteria.

A possible explanation of the difference between the $\mu_{\max }^{\prime}$ based on methane production and acetate consumption may be found in the fact that both processes are not tightly coupled. Acetate consumed in the initial phase of the cultures was only partly converted directly to methane, the other part being stored in an unknown pool, which was eventually converted to methane. This phenomenon was also observed in the initial phase of batch experiments by Huser et al. (1982). De Zeeuw (1984) found that the biomass yield of methanogenic bacteria when growing an acetate was three times higher than when growing on methanol. Since protein formation was the same for both substrates, it was hypothesized that most of the consumed acetate was converted to polymeric reserve material. This could explain our observation, that in the batch culture gas production continued for some time after acetate was depleted. In addition, the persistence of small $\mathrm{pH}$ profiles inside aggregates upon depletion of substrate may be the result of this process. Since the biochemistry and physiology of this acetate consumption and storage process is unknown, activity measurements based on acetate consumption may lead to erroneous conclusions on the kinetics of methanogenesis. Therefore, estimation of kinetic parameters based on methane production is to be preferred for aggregates, and the following discussion is based on these values. Comparison of our observations with previous measurements on suspended growing cells and disintegrated aggregates leads to the conclusion that $\mu_{\max }^{\prime}$ of aggregated bacteria, used in this study, is lower. Possibly, this can be attributed to the use of different strains, however, an interesting electron microscopic study on aggregates of Methanosarcina spp showed that only the bacteria in the outermost cell-layers of these aggregates divide and grow (Bochem et al., 1982). The absence of growth in deeper regions cannot be due to starvation, since the substrate concentration and the $\mathrm{pH}$ hardly change over a cell layer of approx. $20 \mu \mathrm{m}$. This suggests that cell division and growth in aggregates may be subjected to regulation.

The effectiveness factors $\eta$ based on measured methane production as well as those calculated with and without $\mathrm{pH}$ profiles (Table 1) are almost independent of the substrate concentration in the bulk, while the measured values (column $\mathrm{C}$ ) were far from unity.
The explanation is that the influence of acetate transport resistance on the conversion rate is negligible for the relevant $S_{b}$ range. Even at high substrate concentrations $\eta$ did not approach a value of 1 , since the elevated internal $\mathrm{pH}$ value reduced $\mu_{\max }$ and thus the maximal conversion rate. The extent of the $\mathrm{pH}$ profiles depends on the size of the aggregate. The value of $\eta$ of disintegrated aggregates does amount to 1 because even in the largest fragments $(50 \mu \mathrm{m})$ no significant $\mathrm{pH}$ profiles can develop. The effectiveness factors obtained after disintegration are much lower than those calculated with fixed kinetic parameters (no $\mathrm{pH}$ profiles taken into account), but are in good agreement with the calculations using $\mathrm{pH}$ dependent kinetics and comprising the $\mathrm{pH}$ profiles. Therefore, it can be concluded that the model is reliable and $\mathrm{pH}$ profiles are of great importance for the behaviour of methanogenic aggregates.

Reactor behaviour is expected to be strongly influenced by the $\mathrm{pH}$ profiles occurring in aggregates. A decrease of the bulk $\mathrm{pH}$ may result in a lower internal $\mathrm{pH}$ and a concomitant decrease of the local $\boldsymbol{K}_{\mathrm{s}}$ value, leading to a higher biomass activity, especially at low substrate concentrations. Increase of the influent $\mathrm{pH}$ buffer capacity may have the same effect. Moreover, it enables establishment of the optimal $\mathrm{pH}$ value for $\mu_{\max }$ in the whole aggregate.

The measurements of the $\mathrm{pH}$ profiles revealed the existence of a boundary layer of approx. $50 \mu \mathrm{m}$, surrounding the aggregates. This layer increased the surface $\mathrm{pH}$ value by approx. 0.1 units. Thereby it influenced the $\mathrm{pH}$ profiles inside the aggregate to some extent and thus the kinetics of the conversion. An acetate boundary layer also might influence the transport rate of substrate towards the biofilm. However, since the influence of the acetate transport rate on the conversion rate was negligible, the boundary layer for acetate was not significant. Since the $\mathrm{pH}$ boundary layer was small it is unlikely that enhancement of external transport by mixing will increase the conversion rate significantly in methanogenic reactors.

At the moment reliable acetate selective microelectrodes are not available. However, such an electrode would not enable measurement of unionized acetic acid, the actual substrate for methanogenesis, which is determined by the total acetate concentration and the $\mathrm{pH}$. Therefore, information on the acetate profiles without knowledge of the local $\mathrm{pH}$ is not sufficient. Moreover, according to calculations with the structured model, the acetate concentration in aggregates remains almost constant and is close to the bulk concentration.

The medium $\mathrm{pH}$ buffer capacity strongly determined the macrokinetics of methanogenic aggregates by its influence on the $\mathrm{pH}$ profiles in aggregates. $\mathrm{A}$ phosphate concentration of $10 \mathrm{~mol} / \mathrm{m}^{3}$ completely prevented the development of $\mathrm{pH}$ profiles in aggregates and no influence of the substrate concentration on the conversion was found in the substrate 
concentration range from 5 to $30 \mathrm{~mol} / \mathrm{m}^{3}$, due to the low local $K_{\mathrm{s}}$ values. As a consequence, the theoretical prediction of Henze and Harremoës (1983) that mass transfer resistance in methanogenic biofilms is not significant, is only valid in well buffered media. The verification of this prediction by Dolfing (1985) was based on experiments in media buffered with $5 \mathrm{~mol} / \mathrm{m}^{3}$ phosphate, in which the $\mathrm{pH}$ profiles will be strongly reduced.

The conversion rate in aggregates is influenced by the transport resistance for protons. This can be understood by the notion that under physiological conditions proton concentrations are very low, in aggregates varying from $10^{-5}$ to $10^{-4} \mathrm{~mol} / \mathrm{m}^{3}$, and 6 orders of magnitude smaller than the acetate concentration. The mass transfer resistances are sufficiently large to maintain small proton concentrates gradients (maximal value of $2 \times 10^{-1} \mathrm{~mol} / \mathrm{m}^{4}$ ), nevertheless leading to significant $\mathrm{pH}$ gradients. However, limitation of the conversion rate by acetate depletion in the aggregate, under typical reactor conditions, requires much larger concentration gradients. Supposing an acetate bulk concentration of $5 \mathrm{~mol} / \mathrm{m}^{3}$, gradients should amount to at least $2 \times 10^{3} \mathrm{~mol} / \mathrm{m}^{4}$, for which the mass transfer resistances are obviously insufficient. From this study it can be concluded that mass transfer resistance is important in methanogenic aggregates via the influence of the internal $\mathrm{pH}$ on the kinetics. This conclusion is relevant for most industrial reactors, since the phosphate concentration is usually well below $1 \mathrm{~mol} / \mathrm{m}^{3}$. The bulk liquid of the Internal Circulation reactor, from which the investigated aggregates were obtained, is weakly buffered at a $\mathrm{pH}$ value of $6.8-7.1$ by approx. $0.1 \mathrm{~mol} / \mathrm{m}^{3}$ phosphate and $20-25 \mathrm{~mol} / \mathrm{m}^{3}$ carbonate. It was calculated that at the typical acetate concentration in the reactor of $5 \mathrm{~mol} / \mathrm{m}^{3}$ the acetate concentration in the centre of aggregates amounts to $3.73 \mathrm{~mol} / \mathrm{m}^{3}$. Using an alkalinity balance, it can be calculated that in such a medium the $\mathrm{pH}$ in the centre of aggregates amounts to 7.4, which is in good agreement with the presented microelectrode measurements.

The high internal $\mathrm{pH}$ reduced the activity in the centre of the aggregates to $15-30 \%$ of the activity in the peripheral zones. Moreover, the volume of the central part of aggregates $(r / R<0.5)$ is only $10 \%$ of the total volume. Therefore, an additional assumption of a non-homogeneous biomass distribution, assuming an inactive centre, is insignificant for modelling.

Inhibition by sulphide is reported to be strongly influenced by the $\mathrm{pH}$ and it was found that inhibition of methane formation is related to the unionized sulphide $\left(\mathrm{H}_{2} \mathrm{~S}\right)$ concentration (Koster et al., 1986). These authors observed a lower inhibition rate due to sulphide on intact aggregates, as compared to disintegrated aggregates. Since the unionized fraction of sulphide is $\mathrm{pH}$ dependent, they concluded that the $\mathrm{pH}$ inside the aggregates must be higher than in the bulk liquid. Indeed, this conclusion is confirmed directly by our profile measurements. It should be stressed that the mentioned sulphide inhibition experiments were performed in weakly buffered media containing $6 \times 10^{-2} \mathrm{~mol} / \mathrm{m}^{3}$ phosphate.

Previous measurements on aggregates from an upflow anaerobic sludge blanket reactor, fed with incompletely acidified wastewater, showed the presence of an acidifying process (de Beer and Van den Heuvel, 1988), resulting in pH profiles strongly deviating from those reported in this study. Moreover, pH profiles depend on the size of the aggregates, larger aggregates having more pronounced $\mathrm{pH}$ profiles. Since both the processes inside aggregates and their size distribution may depend on the reactor type and composition of the influent, the reported $\mathrm{pH}$ profiles may not be valid for aggregates from other reactors.

Knowledge of $K_{\mathrm{s}}$ and $\mu_{\max }$ only, is not sufficient for the understanding of the behaviour of a methane reactor containing aggregates. This study shows that the mathematical description of the conversion in methanogenic aggregates requires a structured model, comprising $\mathrm{pH}$ micro-profiles and the $\mathrm{pH}$ dependency of the kinetics as postulated by Graef and Andrews (1973) and van den Berg et al. (1975). This result indicates clearly the central role that $\mathrm{pH}$ profiles play in methanogenic aggregates. Both $\mu_{\max }$ and $K_{\mathrm{s}}$, and thus the conversion rate, are strongly influenced by the local $\mathrm{pH}$. Therefore, a mathematical description of the methanogenic conversion in aggregates is impossible without knowledge of the concomitant pH profiles. Since in most microbial conversions net proton consumption or production takes place, this conclusion seems relevant for many processes in which biofilms are involved.

\section{CONCLUSIONS}

The low effectiveness factor of methanogenic aggregates converting acetate to methane and carbonate cannot be explained by mass transfer resistances for acetate. The macrokinetics of these aggregates can be explained by the $\mathrm{pH}$ dependent growth kinetics as postulated by Graef and Andrews (1973) assuming unionized acetic acid to be the actual substrate. Due to the high internal $\mathrm{pH}$ values the conversion rate in the aggregates is reduced kinetically. Therefore, decrease of the reactor $\mathrm{pH}$ may lead to an increase of the methanogenic activity. The mass transfer resistances were large enough for the development of $\mathrm{pH}$ profiles, but insufficient for the development of significant acetate profiles.

Acknowledgement-Support and assistance by Paques BV, Balk, The Netherlands is gratefully acknowledged.

\section{REFERENCES}

de Beer D. and Van den Heuvel J. C. (1988) Gradients in immobilized biological systems. Analyt. chim. Acta 213 , 259-265. 
van den Berg L., Patel G. B., Clark D. S. and Lentz C. P. (1975) Factors affecting rate of methane formation from acetic acid by enriched methanogenic cultures. Can J. Microbiol. 22, 1312-1319.

Bochem H. P., Schoberth S. M., Sprey B. and Wengler P. (1982) Thermophilic biomethanation of acetic acid: morphology and ultrastructure of a granular consortium. Can. J. Microbiol 28, 500-510.

Dolfing J. (1985) Kinetics of methane formation by granular sludge at low substrate concentrations-the influence of mass transfer limitation. Appl. Microbiol. Biotechnol. 22, $77-81$.

Dubourguier H. C., Prensier G. and Albanac G. (1987) Structure and microbial activities of granular anaerobic sludge. In Granular Anaerobic Sludge; Microbiology and Technology (Edited by Lettinga G., Zehnder A. J. B., Grotenhuis J. T. C. and Hulshoff Pol L. W.), pp. 18-33. Pudoc, Wageningen, The Netherlands.

Graef S. P. and Andrews J. F. (1973) Mathematical modelling and control of anaerobic digestion. A.I.Ch.E. Symp. Ser. 136, 101-131.

Hamelers H. V. M. and Koster I. W. (1986) Estimation of the kinetic constants of acetoclastic methanogens from batch experiments. In Proc. EWPCA conf. on Anaerobic Waste Water Treatment, Industrial Presentations, Amsterdam, The Netherlands, pp. 625-628.

Henze M. and Harremoës P. (1983) Anaerobic treatment of waste-water in fixed film reactors-a literature review. Wat. Sci. Technol. 15, 1-101.

Huser B. A., Wuhrmann K. and Zehnder A. J. B. (1982) Methanothrix soehngenii gen. nov. sp. nov., a new acetotrophic non-hydrogen methane bacterium. Archs Microbiol. 132, 1-9.

Koster I. W., Rinzema A., de Vegt A. L. and Lettinga G. (1986) Sulfide inhibition of the methanogenic activity of granuitar sludge at various $\mathrm{pH}$ levels. Wat. Res. 20, 1561-1567.

McCarty P. L. (1964) Anaerobic waste treatment fundamentals. Publ. Wks 95, 107.

Perry R. H. and Green D. (1984) Chemical Engineers' Handbook, 6th edition. McGraw-Hill, New York.

Shieh W. K., Sutton P. M. and Kos P. (1981) Predicting reactor biomass concentration in a fluidized-bed system. J. Wat. Pollut. Control Fed. 53, 1574-1584.

Speece R. E. (1988) A survey of municipal anaerobic sludge digesters and diagnostic activity assays. Wat. Res. 22 , 365-372.

Weber H., Kulbe K. D., Chmiel H. and Trosch W. (1984) Microbial acetate conversion to methane: kinetics, yields and pathways in a two-step digestion process. Appl. Microbiol. Biotechnol. 19, 224-228.

Yang S. T. and Okos M. R. (1987) Kinetic study and mathematical modelling of methanogenesis of acetate using pure cultures of methanogens. Biotechnol. Bioengng 30, $661-667$.

de Zeeuw W. (1984) Acclimatization of anaerobic sludge for UASB-reactor start-up. Ph.D. thesis, Agricultural University Wageningen, The Netherlands.

Zeikus J. G. (1980) Microbial populations in digesters. In Anaerobic Digestion (Edited by Stafford D. A. et al.), pp. 61-87. Applied Science, London.

Zehnder A. J. B. and Wuhrmann K. (1977) Physiology of a Methanobacterium strain AZ, Archs Microbiol. 111, 199-205.

Zehnder A. J. B., Huser B. A., Brock T. D. and Wuhrmann K. (1980) Characterization of an acetate- decarboxylating, non-hydrogen-oxidizing methane bacterium. Archs Microbiol. 124, 1-11. 